\title{
Distribution, Composition, and Abiotic Environment of Silver Rasbora (Rasbora argyrotaenia Blkr) Fish in Upstream Areas of Barito Watershed, South Kalimantan
}

\author{
Erwin Rosadi \\ Fisheries Faculty of Lambung Mangkurat University, Banjarbaru, South Borneo
}

Endang Yuli H

Fisheries and Marine Science Faculty of Brawijaya University, Malang, East Java

Daduk Setyohadi

Fisheries and Marine Science Faculty of Brawijaya University, Malang, East Java

\section{Gatut Bintoro}

Fisheries and Marine Science Faculty of Brawijaya University, Malang, East Java

Received: May 18, 2014 Accepted: June 9, 2014 Published: June 27, 2014

doi:10.5296/jee.v5i1.5880 URL: http://dx.doi.org/10.5296/jee.v5i1.5880

\begin{abstract}
This study aims to find scientific data concerning distribution pattern of $R$. argyrotaenia, catch composition of $R$. argyrotaenia including length frequency data, fishing peak season, spawning season, and abiotic characteristics of aquatic environment, such as life of $R$. argyrotaenia. The findings indicate that distribution pattern of $R$. argyrotaenia during rainy season (January-April) is scattered in main river, tributary, and marsh (flood plain), during dry season (May-August), position of fish is in main river and tributary, while in transitional months (September-December), fish is concentrated in main river. Fishing peak season occurs in April, May, June, and July reaching average haul range of $9.98 \mathrm{~kg} / \mathrm{month}+0.62-12.63$ $\mathrm{kg} / \mathrm{month}+1.08$. Based on Analysis of Progression Model by utilizing FISAT II on length-based data of $R$. argyrotaenia, there found three cohorts by average length of 65.76
\end{abstract}




\section{Macrothink}

$\mathrm{mm}+9.0,116.13 \mathrm{~mm}+15.0$, and $156.63 \mathrm{~mm}+4.7$. Referred to analysis of the Von Bartalanffy growth curve, it is known that inital spawning season of $R$. argyrotaenia alleged that the peak spawning season occurs in September, October, November and December reaching value of $\operatorname{Linf}=173.25, \mathrm{~K}=0.510 /$ year, and $\mathrm{t} 0=0.02$. $R$. argyrotaenia lives in habitat where average temperature is $25.5 \mathrm{oC}+0.12-31.6 \mathrm{oC}+0.12$, current speed of $0.06 \mathrm{~ms}-1+$ $0.02-0.27 \mathrm{~ms}-1+0.02, \mathrm{pH}$ of $4.23+0.03-6.74+0.05$, and DO of $4.2 \mathrm{mg} 1-1+0.06-7.5$ mg $1-1+0.10$.

Keywords: Distribution, Composition, Abiotic Environment, Rasbora argyrotaenia, Barito Watershed 


\section{Introduction}

Fisheries potential in open water values $25 \%$ of total world's fisheries potential (Stiassny, 1996) and open water of Kalimantan Island belongs to one of regions possessing high fish species diversity in Asia (Winemiller, et al., 2008). Width of open water in South Sulawesi is one million hectare (Provincial Government of South Kalimantan, 2011). Exploitation of fish resources in 2010 reaches 62,644.5 ton/year (Fisheries and Marine Services of South Kalimantan, 2011). Exploitation of local fish in South Kalimantan keeps on executing (Rosadi, 2009), and kinds of exploited fish reach 140 species (Prasetyo and Asyari, 2003). One of local fishes which is intensively caught is Silver Rasbora (R. argyrotaenia) fish. It belongs to one of primary commodities giving the greatest contribution to inflation in South Kalimantan in January-October, 2011 (Central Agency on Statistics of South Kalimantan, 2011; Antara News Agency, 2011). High demand on a fish species may trigger high exploitation activity and exploitation intensity to fish resources affecting degradation of the resources itself (Allan, et al, 2005; Alonso et al., 2008; Dudgeon, 2000, 2005; Triyanto, et al, 2009; Muchlisin, et al, 2010). Exploitation activity of R. argyrotaenia is dominantly executed in upstream areas of Barito watershed, tributary, and surrounding marshes (Rosadi, 2009; Chairuddin, et al, 2011) by reaching $80 \%$ of $\mathrm{R}$. argyrotaenia total production in South Sulawesi (Fisheries and Marine Services of Barito Kuala Regency, 2011). Physically, with depth of 8-10 m and width of 400-750 m, Barito River is main river connected to tributary and marsh (flood plain) which $90 \%$ of them is still affected by tides of Java Sea (River Basin Agency of Kalimantan II, 2012; Environment, Sanitary, Tourism and Culture Service of Barito Kuala Regency, 2008).

On purpose of R. argyrotaenia resource stock sustainability in upstream areas of Barito watershed, South Kalimantan, there must have some anticipative and comprehensive efforts heading toward management of fish resource stock. As an initial effort of this management of fish resource stock, scientific data shall be available as an absolute requirement to make decision on fisheries management (FAO, 1995; Allan dan Castillo, 2007; Poff et al., 2006; Lamouroux et al., 2004). Aim of the study is to obtain scientific data concerning on distribution pattern of R. argyrotaenia fish among main river, tributary, and marsh (flood plain), fish catch composition including length frequency data, fishing peak season, spawning season, abiotic characteristics of aquatic environment, such as life of fish.

\section{Research Method}

The study is carried out in upstream area of Barito watershed, South Kalimantan which is located at south latitude of 2057'36.10" and east longitude of 114045'37.92"; and south latitude of 3001 ' 07.86 ' and east longitude of $114045^{\prime} 29.28$ '. It is conducted from June, 2012 to May, 2013. Fish distribution pattern data is obtained by collecting fishing ground data and data of water movement dynamics as acquired from water rising data in form of rainfall data from North Barito station and water flow pattern data (flow accumulation), and also flood prone areas which were generated from SRTM radar imagery data, Digital Elevation Model (DEM), Watershed Delineation Tools (WDT), raster data of flow accumulation and slope map. Fish catch data forms length frequency data collected by fish sampling for one year at 
sampling time interval of one month. Data on abiotic characteristics of aquatic environment is collected every month in week 2 for one year; it consists of temperature measurement, current speed, $\mathrm{pH}$, DO. Data is obtained by in situ like $\mathrm{pH}$ meter, DO meter, water thermometer, current meter, water checker $U$ 22, while measurement is taken in south and north fishing ground in Barito River.

Fish distribution pattern is analyzed by integrating fishing ground data and data of water movement dynamics from water flow pattern (flow accumulation) and slope map/flood prone areas based on Topographic Wetness Index (TWI) and classification of flood prone stage which were developed by Putra (2007). Fish catch data in form of length frequency is analyzed by Progression Analysis Model (Normsep) to illustrate mode of fish cohort agglomeration by utilizing FISAT II program (Sparre and Venema, 1999), Von Bartalanffy method by applying Electronic Length Frequency Analysis (ELEVAN I) to determine initial spawning season and fishing peak season. Both seasons are obtained by analyzing amount of periodic catch in one year fishing season. Otherwise, abiotic characteristics of aquatic environment are analyzed descriptively.

\section{Findings and Discussion}

\subsection{Slope Classification and Water Flow Pattern}

Concerning on regional topography, research site is low land and marsh consisting of Barito River as the main river, tributary and marsh area. By utilizing Digital Elevation Model generated by digital SRTM imagery, research site has angle of elevation by $0-15 \%$; according to Department of Forestry Affairs of Republic of Indonesia (1993), it belongs to flat to sloping land. Thematic map on slope classification of research site is figured in Figure 1. Based on elevation analysis, main water movement is driven by elevation angle ranging from $0 \%$ for the flat land to $15 \%$ for the sloping land.Research site belongs to tropical wet climate characterized by twice changes of monsoon winds (west monsoon wind and east monsoon wind) by the occurrence of two seasons, i.e. rainy season (November-April) and dry season (May-October). Climate is fairly stable in small fluctuation variation all year long due to its closeness to equator.

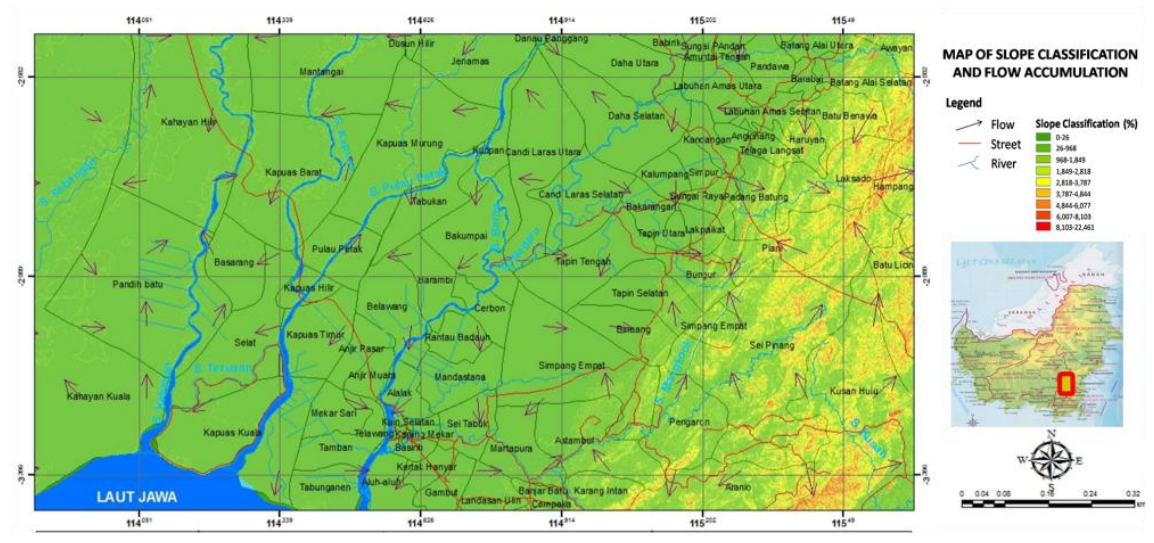

Figure 1. Slope Classification Map in Research Site

Based on the analysis by utilizing Topographic Wetness Index (TWI) formula to determine 
flood prone areas and classification of flood prone stage developed by Putra (2007), then, research site is classified as prone area to highly flood prone area, i.e. an area where periodically caught in a flood based on elevation between $0-15 \%$ by wetness index value of 6.05-23.22 and it is thematically figured in Figure 2.

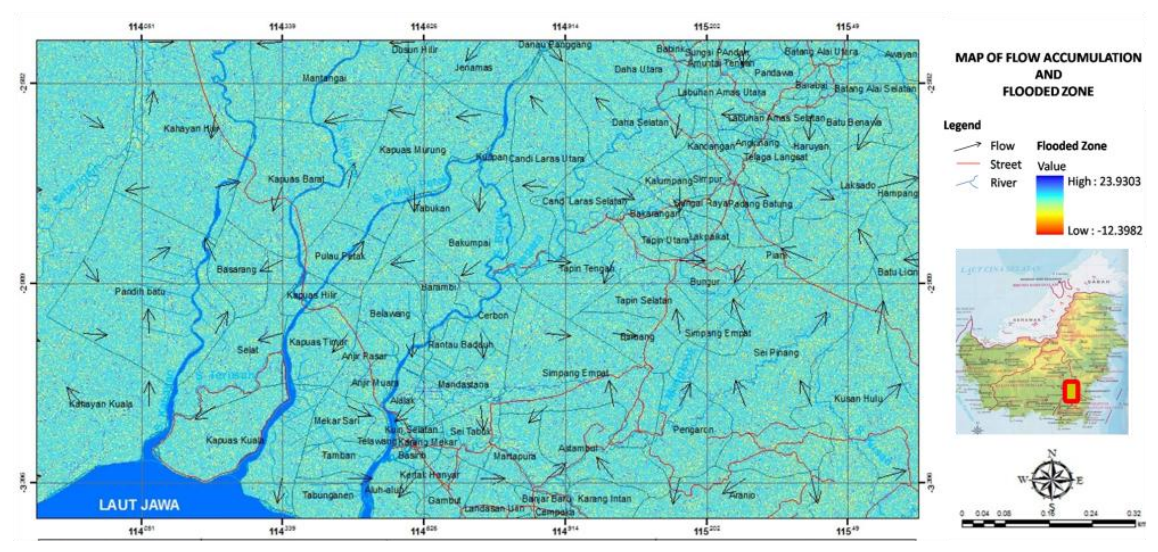

Figure 2. Water Flow Pattern Map in Research Site

Based on average rainfall in Barito watershed (River Basin Agency of Kalimantan II, 2008), high rainfall occurs in November-April. During those months, it potentially gets water overflow from the main river (Barito River) and tributaries flowing to surrounding marsh areas as the flood plain. In May when transition period occurs, rain remains fall in lowering intensity. Otherwise, during June-October, water volume and debit decline significantly. Water flow pattern in November flows from main river to tributary where the water flows from north to south, while water from main river and tributary flows to surrounding marsh in form of water overflow triggered by high rainfall. This phenomenon occurs to April. Water flow pattern in marsh area (flood plain) during these months goes on dynamically (Figure 2). It is triggered by topographic factor of research site where elevation level is classified as sloping land to flat with elevation level of $0-15 \%$ (Figure 1), also it is classified as flood prone to highly flood prone area (Figure 2). In May (transition period), water flow pattern begins to change from marsh water area to main river and tributary. It is driven by declining of rainfall intensity which continues to decline until July. While in August, drought season begins in marsh area (flood plain) until October. Henceforth, during August-December, water flow pattern happens only in the main river and tributary.

\subsection{Distribution Pattern of R. argyrotaenia Fish}

R. argyrotaenia fish belongs to fish cohort executing Potamodromous migration, i.e. fishwhich completely migrates infreshwater ecosystem (Harden Jones 1968; McDowall 1988).Distribution pattern of R. argyrotaenia fish is grounded on position of fishing area as presented in Figure 3. Distribution of R. argyrotaenia during transition period (November-December) moves dynamically in the main river. In January, the fish begins to migrate to tributary and surrounding marsh (flood plain). This phenomenon keeps occuring until April. These months when rainy season comes, R. argyrotaenia distributes evenly to the main river, tributary, and marsh areas. Habitat of genus Rasbora is in river water and marsh area (Zulkifli, et al, 2011; Sulistiyarto, et al, 2007; Arsyad \& Syaefudin, 2010; Feyrer et al., 
2006).

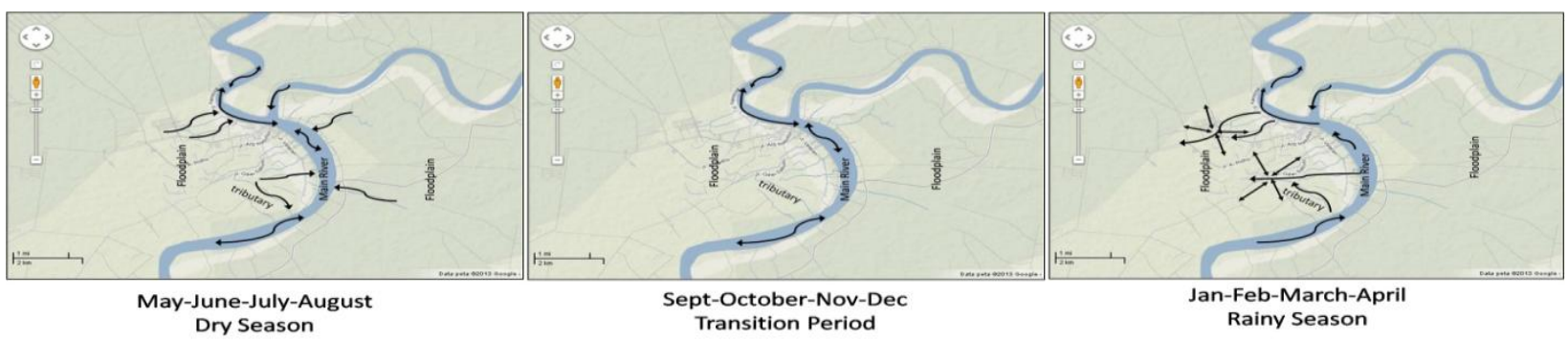

Figure 3.Distribution pattern of R. argyrotaenia is given based on position of fishing area

Type of main river and tributary belong to permanent river since the water remains flooded in the river over all year long, even there occurs yearly flood period causing marsh receives water and being flooded. Pouilly and Rodriguez (2004) assert that yearly flood period indicates seasonal fluctuation of water surface and it belongs to characteristic of aquatic ecosystem around river basin. Seasonal patterncauses water level change that drive water abundance to flood plain, this is prominent thruster in flood plain area (Junk, 1986; Junk et al, 1989) since this area receives nutrient enrichment from the upstream area or available nutrient in its area (Naiman et al, 2005; Tockner et al, 2002). In such natural condition, it will be followed by fish migration heading toward spawning ground and feeding ground (Poulsen et al., 2002; Welcomme, 1969; Winemiller, 1996) or adult stock. When reproduction period comes, mature fishes are looking for spawning location to breed (Effendi, 2003), while seasonal fluctuation during rainy season heighten water level, and biologically, it excites reproduction stimulation to freshwater fish (Lowe-McConnel, 1987; Winemiller, 1996). Then, in May where dry season comes, R. argyrotaenia fish begins to migrate from flood plain to the main river and tributary which occurs to August. During August-October, surrounding marsh water suffers dryness, so fishes only live in the main river and tributary. From then on in September-December (transitional period), fishes only live in the main river, but afterward, they move dynamically toward upstream and downstream areas in regional scale.

\subsection{Fish Catches}

Based on $R$. argyrotaenia fish catches in upstream area of Barito watershed, South Kalimantan, the greatest fish catch is obtained in June by $12.63 \mathrm{Kg} / \mathrm{month}+1.08$, and the smallest fish catch is in January by $2.78 \mathrm{Kg} /$ month+ 1.62. Also on the basis of fish catch, fishing peak season occurs in April-July by fish catch range of $9.98 \mathrm{Kg} / \mathrm{month}+0.61-12.63$ $\mathrm{Kg} / \mathrm{month}+1.08$. This fishing peak season begins in April when rainy season ends, and it continues to May to July during dry season. During this time, fish are migrating from marsh water (flood plain), after having spawning in this area, toward tributaries and main river. This fish migration is utilized by fisherman by blocking fish movement and putting on fishing gear along tributary and main river boundaries. Rosadi (2009) has clarified that fishing peak season of $R$. argyrotaenia takes place in April-July.Certainfishes during dry seasonare isolated in certain places (Winemiller, 1996; Yeni et al., 2013; Utomo dan Krismono, 2006), including fish having capability of utilizing oxygen-rich surface (Winemiller, 1989; Soares et al., 2006). In the following months, i.e. in transitional periods (September-December), R. 
argyrotaenia fish catch is decreasing since fish movement pattern begins to be concentrated in the main river only. In January-March (rainy season) periods, water volume increases in main river, tributary, and surrounding marsh and begins to be flooded. $R$. argyrotaenia movement pattern turns to very dynamic, and distribution spread turns to broader area, so fish catching turns to be more difficult.

\subsection{Composition of Fish'Age (Cohort) Based on Length Distribution}

Cohort analysis result by applying Model Progression Analysis (Normsep), depicts total length mode of $R$. argyrotaenia fish (Figure 4).

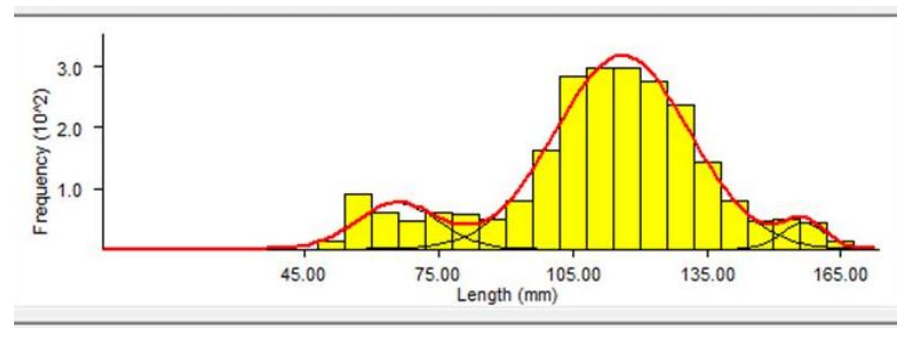

Figure 4. Cohort analysis of $R$. argyrotaenia fish by applying model progression analysis (Normsep)

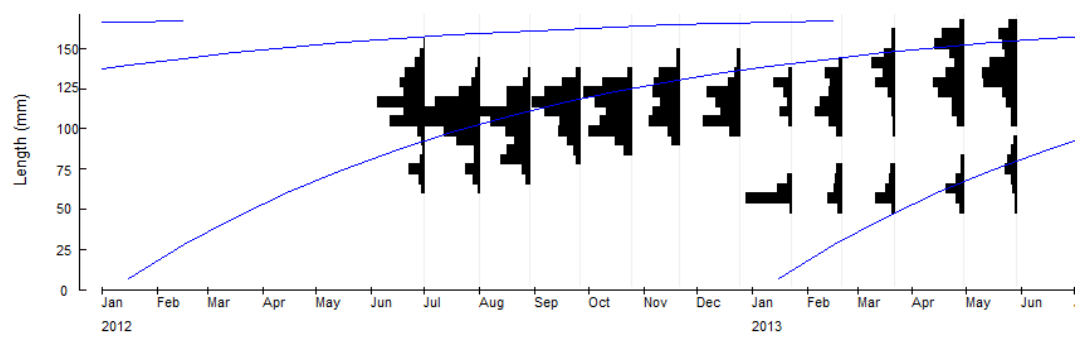

Figure 5. Growth curve of $R$. argyrotaenia based on Von Bartalanffy method

On the basis of Normsep analysis based on total length of $R$. argyrotaenia fish, it is known that there are three fish catch cohorts, i.e. $65.76 \mathrm{~mm}+9.0,116.13 \mathrm{~mm}+15.0$ and 156.63 $\mathrm{mm}+4.7$. Based on Von Bartalanffy growth curve analysis (Figure 5), spawning season takes obtained alleged that the peak spawning season occurs in September, October, November and December by value of $\operatorname{Linf}=173.25, \mathrm{~K}=0.510 /$ year and $\mathrm{t}_{0}=0.02$ year. Fish catch during fishing peak season (April-July), there found three cohorts as follows: first cohort reaches $67.57 \mathrm{~mm} \pm 8.5$, second cohort reaches $125.22 \mathrm{~mm} \pm 9.8$ and the third cohort reaches 152.44 $\mathrm{mm} \pm 5.3$ (Figure 4). Hence, it indicates that utilized fishing gear, i.e. gill net, has caught all age ranges of $R$. argyrotaenia meaning that this method has low selection level. Utomo and Prasetyo (2004), Chairuddin et al. (2011), assert that there is unselective fishing gear operated in Barito river water. Uncontrolled fish catch factor may change relative abundance of the species in aquatic community, and it directly affects water fertility, biomass ecosystem, gonadal maturity age, size of fish caught, or dynamics of food chain (Dudgeon et al., 2006; Taylor et al., 2006; Hutchings, 2004; Shutter and Koonce, 1977; Rochet and Trenkel, 2003). 
Dan Loh et al., (2005), Strayer and Dudgeon (2010) stated that an endangered species in freshwater ecosystems tend to be higher than the existing species in the sea or land. So it is necessary to measure the fish resource management can ensure sustainability offishre sources (Trevor and Julia, 2012) and Neala et al., (2009) suggested that fishing activities conducted prioritize prudence factors that selective fishing on fish size.

\subsection{Environment of Abiotic-Aquatic}

On the basis of observation, color of water has two colors, i.e. blackish brown and brownish yellow. Variation of this color of water is caused by seasonal difference. In dry season, the water is blackish brown-colored, and when rainy season comes, it is brownish yellow-colored. The phenomenon is triggered by occurrence of soil erosion along riparian areas, and then it drifts along to river (Wantzen, 2006). Naughton (1996) explains that turbidity comes about because of mud and precipitative particle, and it is like bounding factor in open water. Difference color of water firmly relates to water turbidity level, otherwise, water turbidity level affects an existence of R. argyrotaenia fish. Muchlisin et al. (2010) asserts that the existence of fish belonging to one genus with R. argyrotaenia, i.e. R. tawerensis when gonadal maturity stage is reached, it always lives in an area with high transparency value. Most of fish species has restrictiveness living in water depth limit (Winemiller and Jepsen, 1998), while abundance offish species relates to water depth (Lakra, et al, 2010; Dekar and Magoulick 2007; Hugueny, 1990). In fishing peak season of R. argyrotaenia in research site, water is blackish brown-colored and fish distribution is 1-3 meter in water depth range from water surface since fishing gear, i.e. gill net, is operated by fisherman in distance of $0.5 \mathrm{~m}$ from water surface; gill net height is $2 \mathrm{~m}$.
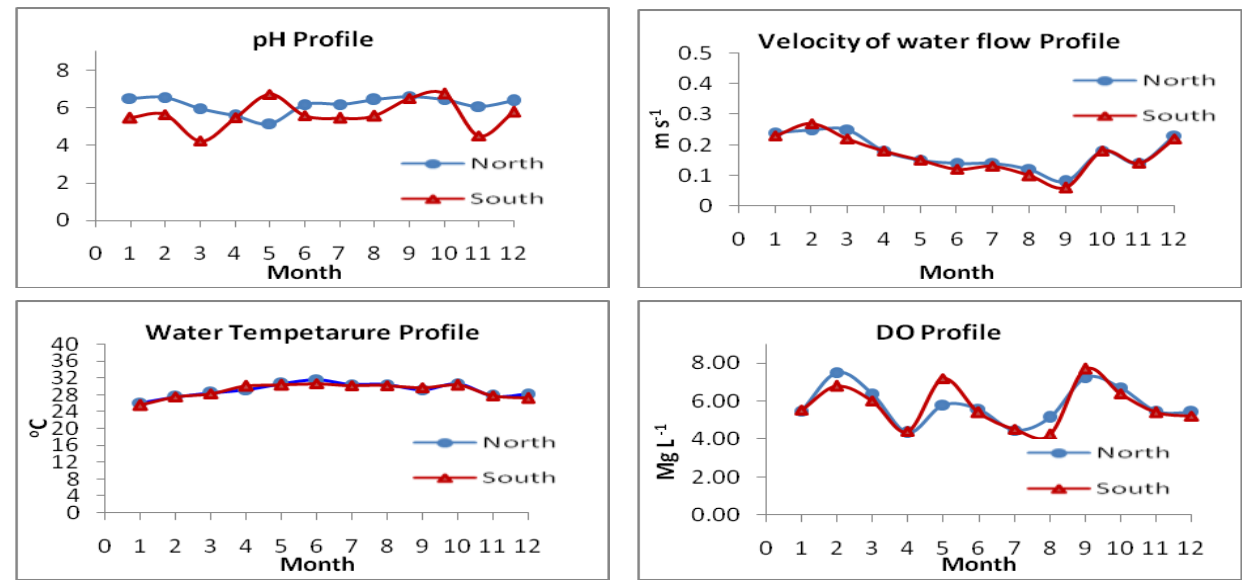

Figure 6. Temperature profile, current speed, $\mathrm{pH}$, and DO in upstream areas of Barito watershed, South Kalimantan

Water temperature range does not depict significant variation of inter-observation periods and inter-measurement locations (north fishing ground and south fishing ground). The highest water temperature of $31.7^{\circ} \mathrm{C}$ happens in dry season, i.e. in June, while the lowest water temperature of $25.4{ }^{\circ} \mathrm{C}$ occurs in rainy season, i.e. January (Figure 6). Average water temperature of inter-observation periods and inter-measurement locations are $25.5^{\circ} \mathrm{C}+0.12$ 
$-31.6{ }^{\circ} \mathrm{C}+0.12$. R. argyrotaenia fish lives at temperature of $20{ }^{\circ} \mathrm{C}-26$ oC (Baensch dan Riehl,1985), 26.4 oC - 30.5 oC (Sulistiarto, 2013) and 27.3 oC - 29.2 oC (Budiharjo, 2002). Water temperature is one of important boundary factors in open water since aquatic organisms have narrow temperature tolerance (stenothermic) (Naughton, 1996). Water temperature fluctuation as habitat of R. argyrotaenia fish falls within relatively high by $>3^{\circ} \mathrm{C}$, and according to Alabaster and Lloyd (1980), water temperature fluctuation is ideal for fish viability if it is $<3{ }^{\circ} \mathrm{C}$. Other researchers, Lowe Mc Connel (1987) and Boyd (1990) assert that most of fishes in tropical area grow well at water temperature range of $25-32{ }^{\circ} \mathrm{C}$, so, on the basis of that fact, water temperature range in research site is good for viability of $\mathrm{R}$. argyrotaenia.

Measurement calculation on current speed does not indicate great variation of inter-measurement locations or inter-measurement periods. The fastest current speed is 0.27 ms-1, it occurs in rainy season, i.e. in February, while the slowest current speed is $0.04 \mathrm{~ms}-1$, it happens in dry season, i.e. in September. Whereas, average current speed of inter-measurement locations and inter-observation periods range around $0.06 \mathrm{~ms}-1+0.02-$ $0.27 \mathrm{~ms}-1+0.02$. In general, current speed increases during rainy season triggered by high rainfall intensity in upstream areas and water flow movement which is normally flowing to place in lower elevation, i.e. downstream areas. Population growth of Rasbora fish is highly affected by factor of river water current, when time goes by; it becomes an appropriate area for this species growth (Shukor, et al, 2008). In a habitat where current flows slowly, it tends to have denser population (Scott, 1979 in Sulistiyarto, 1998). Winemiller and Jepsen (1998) assert current speed is one of boundary factors for most of fish species.

Measurement calculation on acidity value $(\mathrm{pH})$ does not indicate significant variation of inter-measurement locations or inter-observation periods. The highest $\mathrm{pH}$ range is 6.80 occurring in dry season, i.e. in October, while the lowest $\mathrm{pH}$ is 4.13 occurring in the end of rainy season, i.e. in April. Average $\mathrm{pH}$ of inter-measurement locations and inter-observation periods is $4.23+0.03-6.74+0.05$. On the basis of average $\mathrm{pH}$ range, it is classified as less ideal for habitat of $R$. argyrotaenia life. Baensch, H.A. and R. Riehl (1985) assert that R. argyrotaenia lives in $\mathrm{pH}$ range of $6.5-7$ and $5.16-6.54$ (Sulistiarto, 2013), $\mathrm{pH}$ of $7.4-7.9$ (Budiharjo, 2002). Shukor et al. (2008) asserts that population growth of Rasbora fish is greatly affected by $\mathrm{pH}$. Ideal water acidity value $(\mathrm{pH})$ for tropical fish ranges between 6-9 (the Government Regulation of the Republic of Indonesia, 2001; Alabaster and Llyod, 1980), while $\mathrm{pH}$ value of $>10$ and $\mathrm{pH}$ of $<4$ may have fatal results to the fishes (Alabaster and Llyod, 1980; Efendi, 2003), also, if species fertility is positive/negative, it firmly relates to $\mathrm{pH}$ (Lakra, et al., 2010; Tongnunui, et al, 2009). Other researchers, Dodds (2002) and Effendi (2003) assert that ecosystem productivity of water is classified as low if water $\mathrm{pH}$ is <5.0.

Dissolved oxygen (DO) level indicates relative high variation in inter-measurment locations and inter-observation periods. The highest DO range is $7.8 \mathrm{mg} \mathrm{l}-1$ and the lowest one is 4.2 $\mathrm{mg} \mathrm{1-1}$. At the same time, average DO is $4.2 \mathrm{mg} 1-1+0.06-7.5 \mathrm{mg} 1-1+0.10$. Because of seasonal difference, the highest average DO happends in rainy season, i.e. in February, while the lowest one occurs in dry season, i.e. in August. During dry season, dissolved oxygen is too low causing certainfishes are isolated in certain places (Lowe-McConnell, 1964; 
Winemiller, 1996), while natural mortality is caused by low oxygen level (Das and Pande, 1980; Welcomme, 2001). Dissolved oxygen level is boundary factor in water (Lakra, et al, 2010; Tongnunui, et al, 2009; Naughton, 1996) and deoxygenation may have fatal result to fish (Green, et al, 2009). Sulistiyarto (2013) asserts that DO level in flood plain of Rungan River, Central Kalimantan as habitat of R. argyrotaenia fish is 1.8-3.1 mg/l. Minimum DO

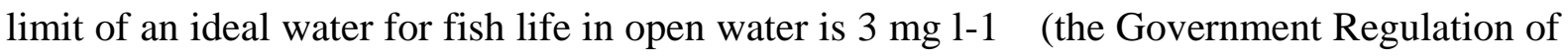
the Republic of Indonesia, 2001). Founded on the reference, dissolved oxygen level in research site is above minimum threshold limit value.

\section{Conclusion}

Distribution pattern of $R$. argyrotaenia in upstream area of Barito watershed, South Kalimantan, during rainy season is evenly distributed in the main river, tributary, and marsh area (flood plain), while during dry season, fish swims to the main river and tributary, and when transition period comes, fish is concentrated in the main river. Fishing peak season comes in April-July. Based on R. argyrotaenia fish catch, there had been caught three cohorts consisting of average length by $65.76 \mathrm{~mm}+9.0,116.13 \mathrm{~mm}+15.0$, and $156.63 \mathrm{~mm}+4.7$. Inital spawning season of $R$. argyrotaenia alleged that the peak spawning season occurs in September, October, November and December reaching value of Linf $=173.25, \mathrm{~K}=$ 0.510 /year, and $\mathrm{t} 0=0.02$. . argyrotaenia fish lives in habitat where average temperature range is $25.5 \mathrm{oC}+0.12-31.6 \mathrm{oC}+0.12$, current speed of $0.06 \mathrm{~ms}-1+0.02-0.27 \mathrm{~ms}-1+0.02$, $\mathrm{pH}$ of $4.23+0.03-6.74+0.05$, and DO of $4.2 \mathrm{mg} \mathrm{l}-1+0.06-7.5 \mathrm{mg} \mathrm{l}-1+0.10$.

\section{References}

Alabaster, J. S., \& Lloyd, R. (1980). Water Quality Criteria for Freshwater Fish. Second edition. Butterworth Scientific. London. England. p. 359.

Allan, J. D., Abell, R., Hogan, Z., Revenga, C., Taylor, B., Welcomme, R. L., \& Winemiller, K.O. (2005). Overfishing of Inland Water. BioSience, 55, 1041-1051. http://dx.doi.org/10.1641/0006-3568(2005)055[1041:OOIW]2.0.CO;2

Allan, J. D., Castillo, M.M. (2007). Stream Ecology, Structure and Function of Running Waters. Second Edition. Pub. Springer. Netherlands. 429 p

Alonso R., Pringle C. M., \& Wantzen K. M. (2008). Tropical Stream Conservation. Tropical Stream Ecology. Edited by David Dudgen. Copyrigth 2008, Elsevier Inc. 107-146

Arsyad, M. N., \& Syaefudin, A. (2010). Food and Feeding Habit of Rasbora (RasboraArgyrotaenia, Blkr) in The Down Stream of Musi River. Proceeding of International Conference on Indonesian Inland Waters II. Research Institute for Inland Fisheries, Palembang. Hal $217-224$.

Badan Pusat Statistik Kalimantan Selatan (2011). Perkembangan Harga Indeks Konsumen/Inflasi Kalimantan Selatan. Berita Resmi Statistik No. 53/11/63/Th. XV, 1 November 2011. $14 \mathrm{~h}$

Baensch, H. A., \& Riehl, R. (1985). Aquarien atlas. Band 2. Mergus, Verlag für Natur- und Heimtierkunde GmbH, Melle, Germany. 1216. 
Balai Wilayah Sungai Kalimantan II, Ditjen Sumberdaya Air, Kementerian Pekerjaan Umum RI. (2008). Rancangan Pola Wilayah Sungai Barito-Kapuas. Banjarmasin. Hal 146.

Balai Wilayah Sungai Kalimantan II, Ditjen Sumberdaya Air, Kementerian Pekerjaan Umum RI. (2012). ReviewPola Wilayah Sungai Barito. Banjarmasin. Hal 1-31

Boyd, C. E. (1990). Water Quality in Ponds for Aquaculture. Alabama Agricultural Experement Station. Auburn University, Alabama. 482.

Budiharjo, B. (2002). Seleksi dan Potensi Budidaya Jenis-jenis Ikan Wader dari Genus Rasbora. Jurnal Biodiversitas, 3(2), 225-230

Chairuddin, Gt., Rosadi, E., Abdurrahman., \& Zain, A. (2011). Studi Lingkungan Perairan Dan Penangkapan Ikan Di Sekitar Bagian Hilir (Sektor G) Jalan Hauling Bat - PT. Pinang Services Indonesia. Banjarbaru

Das, S. M., \& Pande, J. (1980). Pollution, Fish mortality and Environmental Parameters in Lake Nainital. Journal Bombay Nat. Hist. Soc., 79, 100-109.

Dekar M. P., \& Magoulick D. D. (2007). Factors Affecting Fish Assemblage Structure during Seasonal Stream Drying. Ecology of Freshwater Fish, 16, 335-342.

Dinas Lingkungan Hidup, Kebersihan, Pariwisata dan Budaya Kabupaten Barito Kuala. (2008). Data dan Deskripsi Sungai. Surat Nomor 660.1/63/LHKPB. Marabahan Kalimantan Selatan

Dinas Perikanan dan Kelautan Kabupaten Barito Kuala. (2011). Laporan Statistik Penangkapan Ikan Perairan Umum. Marabahan. Kalimantan Selatan

Dinas Perikanan dan Kelautan Provinsi Kalimantan Selatan. (2011). Laporan Statistik Penangkapan Ikan Kalimantan Selatan. Banjarmasin

Dodds, W. K. (2002). Freshwater Ecology. Concepts and Environmental Applications. Academy Press. An Elsivier Science Imprint. San Diego. pp. 569

Doi, A. (1997). A review of taxonomic studies of cypriniform fishes in Southeast Asia. Jap. J. Ichthyol, 44(1), 1-33.

Dudgeon D. (2000). Large Scale Hydrological Alterations in Tropical Asia : Prospects for $\begin{array}{llrr}\text { Riverine } \quad \text { Biodiversity. } & \text { BioSience } & \text { 793-806. }\end{array}$ http://dx.doi.org/10.1641/0006-3568(2000)050[0793:LSHCIT]2.0.CO;2

Dudgeon, D., Arthington, A. H, Gessner, M. O., Kawabata, Z., Knowler, D. J., Leveque, C., Naiman, R. J., Prieur-Richard, A. H., Soto, D., Stiassny, M. L., Sullivan, C. A. (2006). Freshwater biodiversity: importance, threats, status and conservation challenges. Biological Reviews, 81, 163-182.

Effendi, H. (2003). Telaah Kualitas Air bagi Pengelolaan Sumberdaya dan Lingkungan Perairan. Yogyakarta: Kanisius. $256 \mathrm{~h}$

FAO. (1995).Code of Conduct for Responsible Fisheries (CCRF). Rome. 40p 
Feyrer, F., Sommer, T., \& Harrell, W. (2006). Managing Floodplain Inundation for Native Fish. Production Dynamic of Age-0 Splittail (Pogonichthys macrolepidotus) in California's Yolo Bypass. Hidrobiologia, 573(1), 213-226.

Green, J., S. A. Corbet, E. Watts (née Betney), Oey Biauw Lan. (2009). Ecological studies on Indonesian lakes. Overturn and restratification of Ranu Lamongan. Journal of Zoology, 180(3), 315-354. http://dx.doi.org/10.1111/j.1469-7998.1976.tb04681.x

Harden Jones, F. R. (1968). Fish Migration. London: Arnold.

Hugueny, B. (1990). Richesse des peuplements de poissons dans le Niandan (Haut Niger, Afrique) en fonction de lataille de la riviére et de la diversité du milieu. Rev. Hydrobiol. Trop. $23,351-364$.

Hutchings, J. A. (2004). The cod that got away. Nature, 428, 899-900.

Junk, W. J. (1986). Aquatic plants of the Amazon system. In B.R. Davies and K.F. Walker (eds.) The Ecology of River Systems. pp. 319-337. W. Junk, Dordrecht, Netherlands

Junk, W. J., Bayley, P. B., \& Sparks, R. E. (1989). The flood pulse concept in river-floodplain systems. In D.P. Dodge (Ed.), Proceedings of the International Large River Symposium. Can. Spec. Publ. Fish. Aquat. Sci.106, 110-127

Kantor Berita Antara. (2011). Banjarmasin Alami Deflasi. Edisi Kamis, 03 November 2011.

Lakra, W.S., Uttam Kumar Sarkar, Rupali Sani Kumar, Ajay Pandey, Vineet Kumar Dubey, Om Prakash Gusain Published. (2010). Fish diversity, habitat ecology and their conservation and management issues of a tropical River in Ganga basin, India. Springer Science Business Media, LLC 2010 Environmentalist (2010), 30, 306-319.

Lamouroux, N., Dole'dec, S., Gayraud, S. (2004). Biological traits of stream macroinvertebrate communities: effects of microhabitat, reach, and basin filters. Journal of the North American Benthological Society, 23, 449-466.

Loh, J., Green, R. H., Ricketts, T., Lamoreux, J., Jenkins, M., Kapos, V., \& Randers, J. (2005). The Living Planet Index: using species population time series to track trends in biodiversity. Philosophical Transactions of the Royal Society B, 260, 289-295.

Lowe-McConnell, R. H. (1987). Ecological Studies in Tropical Fish Communities. Cambridge University Press, Cambridge. http://dx.doi.org/10.1017/CBO9780511721892

McDowall, R. M. (1988). Diadromy in Fishes: Migrations Between Freshwater and Marine Environments.London: Croom Helm.

Muchlisin, Z. A., Musri Musman, \& MN Siti Azizah. (2010). Spawning seasons of Rasbora tawarensis (Pisces: Cyprinidae) in Lake Laut Tawar, Aceh Province, Indonesia. Reproductive Biology and Endocrinology Journal

Naiman, R. J., Décamps, H., \& McClain, M. E. (2005). Riparia: Ecology, Conservation, and Management of Streamside Communities. Elsevier, New York. 
Naughton and Wolf. (1990). Ekologi Umum. Edisi kedua. UGM Press. Yogyakarta

Neala, W. Kendall, Jeffrey, J. Hard, \& Thomas, P. Quinn. (2009). Quantifying six decades of fishery selection for size and age at maturity in sockeye salmon. Evolutionary Applications ISSN 1752-4571. Journal compilation 2009 Blackwell Publishing Ltd 2 (2009) 523-536 . http://dx.doi.org/10.1111/j.1752-4571.2009.00086.x

Pemerintah Provinsi Kalimantan Selatan. (2011). Potensi Kelautan dan Perikanan Provinsi Kalimantan Selatan. http://www.kalselprov.go.id. Diakses pada 11 Agustus 2011 pukul 20.30 WIB.

Peraturan Pemerintah Republik Indonesia No. 82 Tahun (2001). Pengendalian Pencemaran Air dan Pengelolaan Kualitas Air. p. 28.

Poff, N. L., Olden, J. D., Nicole, K. M., Vieira, N. K. M., Finn, D. S., Simmons, M. P., Kondratieff, B. C. (2006). Functional trait niches of North American lotic insects: traits-based ecological applications in light of phylogenetic relationships. Journal of the North American Benthological Society, 25, 730-755.

Pouilly, M., \& Rodriguez, M. A. (2004). Determinism of Fish Assemblage Structure in Neotropical Floodplain Lakes: Influence of internal and Landscape Lake Conditions. In Welcomme R, Petr T, editors. Proceedings of the Second International Symposium on the Management of Large River for Fisheries (LARS2) Volume II. FAO Regional Office for Asia and the Pacipic, Bangkok, Thailand.

Poulsen, A. F., Ouch, P., Sintavong, V., Ubolratana, S., \& Nguyen, T. T. (2002). Fish migrations of the lower Mekong River Basin: implications for development, planning and environmental management. MRC Technical Paper No. 8. Phnom Penh: Mekong River Commission. Available at http://archive.iwlearn.net/www.mrcmekong.org/ download/free_download/Technical_paper8.pdf

Prasetyo, D., \& dan Asyari. (2003). Inventarisasi Jenis Ikan dan Karakteristik Sungai Barito. Prosiding Pusat Riset Perikanan Tangkap. Badan Riset Kelautan dan Perikanan. Departemen Kelautan dan Perikanan RI. Jakarta: 37-42

Putra, E. H. (2007). Menentukan Lokasi Daerah Rawan Banjir (Studi Kasus provinsi Sulawesi Utara) Menggunakan Metode TWI. Pengendali Ekosistem Hutan. Indonesia

Rochet M. J., \& Trenkel V. (2003). Which community indicators can measures the impact of fishing? A review and proposals. Can Journal Fish Aquat Sci., 60, 86-99. http://dx.doi.org/10.1139/f02-164

Rosadi, Edi. (2009). Prospek Pemasaran Ikan Seluang (Rasbora sp.) Kering di Kabupaten Barito Kuala Provinsi Kalimantan Selatan. (Tesis) Pasca Sarjana Fakultas Perikanan Universitas Lambung Mangkurat. Banjarbaru

Shukor, M. N., Samat, A., Ahmad, A. K., \& Ruziaton, J. (2008). Comparative Analysis Of Length-Weight Relationship Of Rasbora Sumatrana In Relation To The Physicochemical Characteristics In Different Geographical Areas In Peninsular Malaysia. Malays. Appl. Biol. , 
37 (I), 21-29.

Shutter B. J., \& Koonce J. F. (1977). A dynamic model of the western Lake Erie walleye (stizostedion vitreum vitreum) population. Journal Fish Res Board Can, 34, 1972-1982. http://dx.doi.org/10.1139/f77-264

Soares, M. G. M., Menezes, N. A., \& Junk, W. J. (2006). Adaptations of Fish Species to Oxygen Depletion in a Central Amazonian Floodplain Lake. Hydrobiologia, 568, 353-367.

Sparre, P., \& Venema, S. C. (1999). Introduksi Pengkajian Stok Ikan Tropis.Diterjemahkan oleh Puslitbangkan. Jakarta: Pusat Penelitian dan Pengembangan Perikanan, 438.

Stiassny, M. L. J. (1996). An Overview of Freshwater Biodiversity: with some lessons from $\begin{array}{llll}\text { African } & \text { Fishies. } & \text { Fisheries, } & \text { 7-13. }\end{array}$ http://dx.doi.org/10.1577/1548-8446(1996)021<0007:AOOFB>2.0.CO;2

Strayer, D. L., \& Dudgeon, D. (2010). Freshwater biodiversity conservation: recent progress and future challenges. Journal of the North American Benthological Society, 29, 344-358.

Sulistiyarto B. (2013). Hubungan antara Kelimpahan Ikan Saluang (Rasbora argyrotaenia Blkr) dengan Populasi Fitoplankton di Dataran Banjir Sungai Rungan Kalimantan Tengah. Jurnal Ilmu Hewani Tropika, 2(1), 27-30.

Sulistiyarto B., Sedharma D., Rahardjo M. F., \& Sumardjo. (2007). Pengaruh Musim terhadap Komposisi Jenis dan Kelimpahan Ikan di Rawa Lebak, Sungai Rungan, Palangkaraya, Kalimantan Tengah. J. Biodiversitas, 8(4), 270-273.

Sulistiyarto, B. (1998). Pengaruh Beberapa Komponen Habitat Terhadap Kelimpahan Anak Ikan Seluang (Rasbora sumatrana) di Rawa Bebengkel Palangkaraya. Tesis. Bogor: Program Studi Ilmu Perairan, Program Pascasarjana. Institut Pertanian Bogor. 80 h.

Taylor, B. W., Flecker, A. S., Hall, R. O. Jr. (2006). Loss of a harvested fish species disrupts carbon flow in a diverse tropical river. Science, 313, 833-836.

Tockner, K., \& Stanford, J. A. (2002). Riverine flood plains. present state and future trends. Environmental Conservation, 29, 308-330. http://dx.doi.org/10.1017/S037689290200022X

Tongnunui, S., \& F.W.H. Beamish. (2009). Habitat and relative abundance of fishes in small rivers in eastern Thailand. Environmental Biology of Fishes J.

Trevor D. Davies \& Julia K. Baum. (2012). Extinctions Risk and Overfishing: Reconciling Conservation and Fisheries Perspectives on the Status of Marine Fishes. Sceintific Reports Journal, 2, 561. http://dx.doi.org/10.1038.srep00561

Utomo, A. D., \& dan Krismono. (2006). Aspek Biologi Beberapa Jenis Ikan Langka di Sungai Musi Sumatera Selatan. Prosiding Seminar Nasional Ikan IV. Jatiluhur. 29-30 Agustus 2006.

Utomo, A.D., dan Prasetyo, D. (2004). Evaluasi Kegiatan Penangkapan dan Selektivitas Alat Tangkap. Sosialisasi Hasil Penelitian Tahun 2003. Balai Riset Perikanan Perairan Umum. Laporan Teknis. Palembang: 21-31 
Wantzen, K. M. (2006). Physical pollution: effects of gully erosion in a tropical clear-water stream. Aquatic Conservation, 16, 733-749.

Welcomme, R. L. (1969). The biology and ecology of the fishes of a small tropical stream. $\begin{array}{lllll}\text { Zool. Journal. Sinn. } & \text { Soc. } & \text { 485-529. }\end{array}$ http://dx.doi.org/10.1111/j.1469-7998.1969.tb02164.x

Welcomme, R. L. (2001). Inland Fisheries, Ecology, and Management. London:Fishing News Book, A division of Blackwell Science. 358.

Winemiller, K. O. (1996). Dynamic diversity: fish communities of tropical rivers. In Long-term Studies of Vertebrate Communities (M.L. Cody and J.A. Smallwood, Eds.), pp. 99-134. Academic Press, San Diego. http://dx.doi.org/10.1016/B978-012178075-3/50006-4

Winemiller, K. O. (1996). Dynamic diversity: fish communities of tropical rivers. In Long-term Studies of Vertebrate Communities (M.L. Cody and J.A. Smallwood, Eds.), pp. 99-134. Academic Press, San Diego. http://dx.doi.org/10.1016/B978-012178075-3/50006-4

Winemiller, K. O., \& D. B. Jepsen. (1998). Effects of seasonality and fish movement on tropical river food webs. Journal of Fish Biology, 53(Supplement A), 267-296. http://dx.doi.org/10.1111/j.1095-8649.1998.tb01032.x

Winemiller, K. O., Agostinho, A. A., \& Caramaschi E. P. (2008). Fish Ecology in Tropical Streams. Tropical Stream Ecology. Edited by David Dudgen. Copyrigth 2008, Elsevier Inc. 107-146

Winemiller, K.O. (1989). Development of dermal lip protuberances for aquatic surface respiration in South American characid fishes. Copeia, 1989, 382-390. http://dx.doi.org/10.2307/1445434

Yeni Rahman, Tri Rima Setyawati, \& Ari Hepi Yanti. (2013). Karakteristik Populasi Ikan Biawan (Helostoma temminckii Cuvier) di Danau Kelubi Kecamatan Tayan Hilir. Journal Protobiont, 2(2), 80-86.

Zulkifi, H., Setiawan, D, \& Yustian, I. (2011). Freshwater Fish Diversity in Pulokerto Musi River, Palembang-South Sumatra: A Preliminary Results. Paper presented on The 6th CRISUCUPT Conference, International Seminar and Exhibition: Exploring Research Potentials, Palembang, October 20 - 22nd 2011. 